\title{
Arabs Want Democracy, but What Kind?
}

\author{
Sabrina de Regt \\ Research Centre for Longitudinal and Life Course Studies, University of Antwerp, Antwerp, Belgium \\ Email: sabrina.deregt@ua.ac.be
}

Received October 23 $3^{\text {rd }}, 2012$; revised November $20^{\text {th }}, 2012$; accepted December $8^{\text {th }}, 2012$

\begin{abstract}
In recent times, Arabs have shown the world that they are ready for additional democratic reforms. We must nevertheless question what democracy means to them. How do they think about the role of religious leaders in democracy? Does democracy imply extending the rights of women? How do Arabs see the connection between democracy and a prosperous economy? Answers to these and similar questions are important in order to interpret the high levels of support for democracy that are being observed in the Arab world, as well as the possible outcomes of the Arab spring. It is also important to examine whether Arabs have a common understanding of democracy or whether they disagree on the form that democracy should take. Wide variations in the meaning of democracy could retard the process of democratization. In this article, public opinion data from Egypt, Iraq, Jordan, and Morocco are used to develop a detailed image of what democracy means to Arabs.
\end{abstract}

Keywords: Democracy; Religiosity; Women; Economy; Arab World; World Values Survey

\section{Introduction}

The world recently witnessed the Arab Spring. Millions of people demonstrated, sometimes at the risk of their own life, for more democracy and human rights. It is assumed that democracies can survive only if the public supports the principles of democracy (e.g. Stevens, Bishin, \& Barr, 2006). Several authors have shown that levels of support for democracy in Arab countries are high (e.g. Inglehart, 2003; Norris \& Inglehart, 2004). It is not clear, however, which type of democracy Arabs want. The figures that indicate high levels of support for democracy are difficult to interpret if we do not know exactly how Arabs understand democracy. It is not clear whether the democracy for which there is so much support in Arab countries resembles democracy as it is known in many Western countries. It is possible to embrace democracy as an abstract ideal while also subscribing to illiberal convictions that could include banishing dissident voices or disliked groups from the public sphere (Schedler \& Sarsfield, 2007). A full understanding of the way in which Arabs view democracy is essential in order to predict the implications of the Arab Spring for the likelihood of democratization in the Arab World, as well as the possible consequences that such a process could have for international relations. This article presents a detailed empirical picture of how publics in Egypt, Iraq, Jordan, and Morocco view democracy.

\section{Difficulties Defining Democracy}

Scholars have long theorized about what democracy exactly is. Some authors provide minimalist definitions. For example, Schumpeter (1942) argues that a democratic method requires granting individuals the power to decide by means of a competitive struggle for the people's vote. Other authors adopt a more maximalist definition, as does Diamond (1999) who states that competitive, multiparty elections are not sufficient for liberal democracy. Other necessary components of democracy include political equality of citizens under the law, an independ- ent judiciary, independent media, and civil liberties (see e.g. Dahl, Shapiro, \& Cheibub, 2003 for more discussion on defining democracy).

The fact that scholars differ in their definitions of democracy highlights the perils of adopting one-size-fits-all conceptualizations to denote mass views of democracy (Canache, 2006). Nevertheless, remarkably few studies have been conducted on how citizens exactly understand democracy (see e.g. Arensmeier, 2010; Bratton \& Mattes, 2001; Shin \& Cho, 2010 for notable exceptions). This is remarkable, not only because of the lack of consensus among scholars, but even more because of the practical implications of these understandings. Studies have demonstrated that the relationship between Islam and democracy depends upon how democracy is operationalized (Midlarsky, 1998). Most people around the globe say that they would prefer a democratic political system (e.g. Norris, 1999). What does this mean? What, if anything, does the abstract term democracy mean to ordinary people? What do they consider the most defining components of democracy? Previous studies have shown that most ordinary people consider the concept of democracy highly complex and extremely difficult (Sigel, 1979). Studies conducted in established Western democracies, Eastern Europe, Asia, Latin America, and Africa show that about $20 \%$ to $25 \%$ of respondents cannot state what democracy means (Dalton, Shin, \& Jou, 2007). It can be argued that citizens who have lived in countries that have been dominated by authoritarian rule for decades are particularly likely to have trouble defining democracy, as they have no experience with such a political system. The first essential question to be answered in this paper therefore concerns whether Arabs are capable of providing a definition of democracy.

\section{Democracy and Islam}

For many years, both democracy and public opinion polls were found only in the advanced industrial nations of Western Europe and North America (Diamond \& Plattner, 2008). The 
Arab understanding of democracy could be expected to differ from the Western view for several reasons. The first concerns the role of Islam. In his controversial Clash of Civilizations thesis, Huntington (1993) states that Islam and democracy are incompatible. Most studies have shown that there are no significant differences between the populace of Western countries and that in Muslim religious cultures with regard to support for democratic ideals (e.g. al-Braizat, 2002; Díez-Nicolás, 2007; Dixon, 2008; Huang, 2005; Meyer, Tope, \& Price, 2008; Norris $\&$ Inglehart, 2004). It has also been shown that, at the individual level, support for democracy is not necessarily lower among individuals with strong Islamic attachments (e.g. Rose, 2002; Tessler, 2002a; Tessler, 2002b; Toros, 2010). Even if the level of support for democracy is comparable, however, there can be differences in the exact understandings of democracy held by people from the Western world and by those in the Arab world. While most democratic Western countries perceive that state and religion should be separated, the majority of Arabs consider democracy compatible with Islamic (Sharia) law (Grant \& Tessler, 2002). Survey results suggest that Arabs do not necessarily prefer secular democracy: 56\% of Arab respondents agreed that religious authorities should influence government decisions, while 44\% disagreed (Jamal \& Tessler, 2008). Other studies have also found that significant proportions of Arabs with a preference for a democratic political system believe that Islam should play an important role in political affairs (Jamal, 2006; Mogahed, 2006; Tessler \& Gao, 2005; Tessler, Moaddel, \& Inglehart, 2006).

\section{Democracy and Economic Prosperity}

Another notable issue concerns the consideration of democracy in terms of economic outputs. The causes of the Arab Spring include high levels of unemployment and poverty. Some argue that the main reason that Arabs are calling for greater democracy is that they believe this will improve their material living conditions. Maslow's (1943) famous Hierarchy of Needs can explain why people would need enough food, water, clothes, employment, and housing before they could value such abstract elements of democracy as freedom, equality, and human rights. Research has shown that Muslims add an egalitarian and consensual spin to their interpretations of democracy. They are more likely than non-Muslims are to associate democracy with equality and justice (Bratton, 2003). In their investigation of the Arab aspiration for democracy, Jamal and Tessler (2008) report that half of their respondents emphasized economic considerations over political rights and freedom when asked to identify the most important factors that define democracy. They conclude that, at least for some Arabs, the important point is not so much that democracy is the "right" political system in a conceptual sense than it is that democracy is a "useful" form of government.

\section{Democracy and Gender Equality}

Women in Arab countries experience greater economic, political, and social disadvantage relative to men (Moghadam, 2004). For example, Arab countries have the worst record for the political representation of women. The latest available figures show that about $11 \%$ of the representatives in both the lower and upper houses of the legislatures in Arab States are women, as compared to about $23 \%$ in Europe and the Americas ${ }^{1}$. As another example, only $21.6 \%$ of women are employed in the Middle East, as compared to $48 \%$ of the women in developed economic countries and the European Union are active on the labor market ${ }^{2}$. Studies have shown that support for gender equality is closely linked to a society's level of democracy (Inglehart \& Norris, 2003; Inglehart, Norris, \& Welzel, 2002). Moreover, it is argued that the subordination of women in Muslim-majority countries is the most important factor underlying their democratic deficit (Fish, 2002). In a test of the "clash of civilizations" thesis in 72 countries, Norris and Inglehart (2002) conclude that gender equality is involved in the most fundamental fault line between Western and Islamic countries. Rizzo, Abdel-Latif, and Meyer (2007) demonstrate the need to refine this conclusion. First, significant differences have been identified between Arab and nonArab Muslim societies with regard to the approval of gender equality. More notably, in non-Arab Muslim countries, respondents who supported gender equality were more likely to support democracy, while the reverse was true in Arab countries. While the majority of Arabs support democracy as a system of governance, they do not extend the idea of democracy to include women.

\section{Consensus on the Meaning of Democracy}

While there is considerable consensus in the United States regarding the meaning of democracy in terms of liberty and freedom, transitional democracies exhibit wide variation in views of democracy (Camp, 2001). Low levels of consensus on the form that democracy should take reduce the likelihood of a successful transition to a democratic political system. Evidence from Latin America shows that younger people and those who are more educated and more informed are more likely to emphasize liberty when defining democracy (Moreno, 2001). Furthermore, men in Latin America seem to stress liberty somewhat more than women do (Lagos, 2008). In Asia (e.g., Japan) people above the age of 40 were most likely to define democracy in terms of freedom and liberty, while younger respondents offered few specific ideas regarding the meaning of democracy (Ikeda \& Kohno, 2008). In this article, we examine whether Arabs have a common understanding of democracy or whether large variation exists regarding the defining characteristics of democracy. In summary, this paper addresses the following questions:

1) Are Arabs able to define democracy?

2) How do Arabs view democracy?

3) Is there consensus in Arab countries on the definition of democracy?

\section{Data and Measurement}

In order to answer these questions, we draw upon the fourth wave (2005) of the World Values Survey (WVS). Data are available for four Arab countries: Egypt (survey year: 2008), Iraq (2006), Jordan (2007), and Morocco (2007). The WVS is often employed to study democratic orientations around the globe (e.g. Ciftci, 2010; Hofmann, 2004; Huang, 2005; Inglehart \& Norris, 2003; Norris \& Inglehart, 2002). In 2005, the questionnaire introduced a question on the understanding of democracy:

\footnotetext{
${ }^{1}$ http://www.ipu.org/wmn-e/world.html

${ }^{2}$ Women in labour markets: Measuring progress and identifying challenges. International Labour Office. Geneva, 2010.
} 
Many things may be desirable, but not all of them are essential characteristics of democracy. Please tell me for each of the following things how essential you think it is as a characteristic of democracy $(1=$ Not an essential characteristic of democracy and $10=$ An essential characteristic of democracy).

1) Governments tax the rich and subsidize the poor

2) Religious authorities interpret the laws

3) People choose their leaders in free elections

4) People receive state aid for unemployment

5) The army takes over when government is incompetent

6) Civil rights protect people's liberty against oppression

7) The economy is prosperous

8) Criminals are severely punished

9) People can change the laws in referendums

10) Women have the same rights as men

Welzel (2011), Norris (2011) and other scholars have also used this scale in order to examine how people understand democracy. This list is assumed to contain all or most of the features that Arabs might consider important. If this list is incomeplete, we might draw suboptimal or even invalid conclusions (Miller, Hesli, \& Reisinger, 1997). Research using open-end questions on the meaning of democracy does not suggest that any broad categories are missing from this list (see e.g. Chu, Diamond, Nathan, \& Shin, 2008; Seligson, 2001 for a list of categories based upon an open-ended question). We are therefore confident that the list we employed in this study allows us to assess the meaning of democracy in the Arab world. The most important feature of this question is its ability to rank the defining components of democracy. Partial evidence exists regarding how Arabs view democracy. In this study, however, information will be obtained on which components Arabs consider most important for democracy and which components are relatively less important.

\section{Short Country Description}

Although all four countries are part of the Arab World, each has its own specific socio-economic and political pathways. Before presenting the results on how the public in Egypt (population 84 million), Iraq (31 million), Jordan (6.5 million), and Morocco ( 32 million) view democracy, we briefly discuss several major differences between the countries.

Economy: ${ }^{3}$ Egypt has the highest per capita GDP (\$6500), followed by Jordan and Morocco (\$5900 and \$5100, respectively). Iraq has a per capita GDP of about $\$ 3900$. Closer examination of the GDP reveals that, while the service sector makes the largest contribution to the total GDP in Egypt (45.8\%), Jordan (65.2\%), and Morocco (51\%), the industrial sector is the largest component of the economy (62.2\%) in Iraq. Unemployment is a major source of economic insecurity in many Arab countries. The estimated unemployment rate in the four Arab countries varies between $9.20 \%$ in Morocco to $15 \%$ in Iraq (the unemployment rate in Egypt and Jordan is about 12\%). The high levels of youth unemployment are particularly challenging. The CIA reports that between one-fourth and a quarter of all young people (15 - 24 years of age) are unemployed (Egypt, 24.8\%; Jordan, $27 \%$; and Morocco, 21.9\%). About 20\% of Egyptians, $25 \%$ of Iraqis, $14.23 \%$ of Jordanians, and $15 \%$ of Moroccans are living below the poverty line. The four Arab countries addressed in this study have moderate levels of income inequality (Gini index:

${ }^{3}$ These figures were obtained from the CIA World Factbook: www.cia.gov/ library/publications/the-world-factbook.
Egypt, 34.4; Jordan, 39.7; and Morocco, 40.9).

Politics: Freedom in the World is an annual comparative assessment of global political rights and civil liberties ${ }^{4}$. At the time of the survey, as well as in the most recent assessment, Egypt and Iraq were considered not free. At the time that the fourth wave of the WVS was held, Jordan was rated as partly free, although the most recent assessment released by the Freedom House rates Jordan as not free. The reason stated for this status change is the dismissal of the parliament by the king in 2009, along with his announcement that elections would be postponed and the increased influence of the security forces on political life. From the beginning of the country ratings in 1972, Morocco has been evaluated as partly free. This includes Morocco among the countries with the most liberal reforms in the Arab world. Intra-regional variation exists with regard to the intensity and the success of the revolutionary demonstrations of the Arab Spring. The massive protests on Cairo's Tahrir square and elsewhere in Egypt resulted in Mubarak's resignation from office in February 2011. Demonstrations also took place in Iraq, Jordan, and Morocco, albeit to a lesser extent. In response to the political unrest, Iraqi Prime Minister Nouri al-Maliki announced that he would not run for a third term in 2014. In Jordan, protests resulted in ministers being fired, and in Morocco, King Mohammed VI announced constitutional reforms, including more executive power for the parliament and the designation of Berber as an official language.

\section{Non-Response in Defining Essential Characteristics of Democracy}

We must first examine whether Arabs are able to indicate what, if anything, democracy means to them. In order to conclude whether Arabs differ in their understanding of democracy from people living in free Western democracies, we also display figures on people living in several Western democracies (i.e., Australia, Canada, Finland, France, Germany, Great Britain, the Netherlands, Norway, Sweden, Switzerland, and the United States). We do not deny that variation exists within Western democracies as well. Given that this paper concerns how Arabs view democracy, however, the figures on people living in Western democracies are included only as point of reference. Figure 1 displays the percentage of missing values on the question on regarding the defining characteristics of democracy.

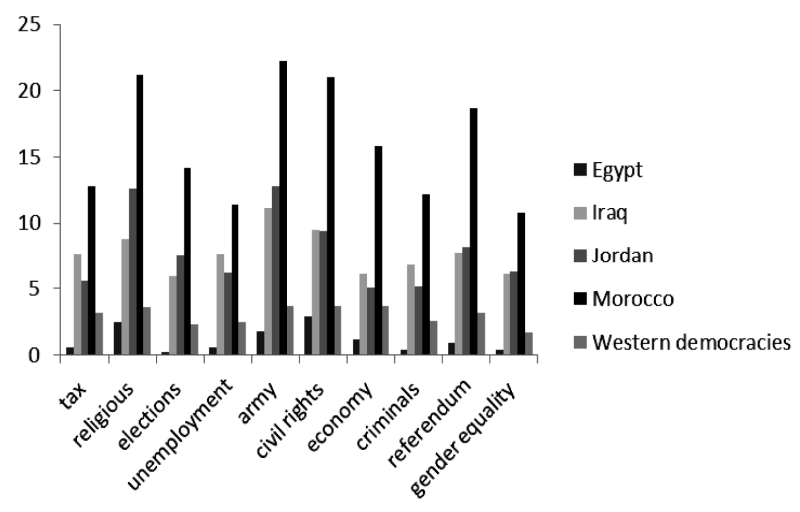

Figure 1.

Percentage missing values on defining essential characteristics of democracy in the Arab World. Notes: Own calculations WVS2005.

\footnotetext{
${ }^{4}$ www.freedomhouse.org/report-types/freedom-world
} 
This figure reveals several notable differences between Arab countries. The level of non-response is extremely low in Egypt, even lower than in Western democracies. For most characteristics, the percentage of missing values is below $1 \%$, and it never exceeds 3\%. The number of missing values in Morocco is considerably higher (twice the number of missing values in Iraq and Jordan, and more than ten times higher in comparison to Egypt). Arabs were most uncertain about the role of religious authorities and the army. In general, we can conclude that most Arabs were able to define democracy. Even though the non-response rate was relatively high in Morocco, most of the respondents in this country did indicate whether they considered several characteristics as important characteristics of democracy. It would be interesting to know why some Arabs did not answer the questions concerning the content of democracy. This could have been because they did not know the answer, although it also could have been that they refused to answer the questions, perhaps out of fear for the authorities. Missing values in Iraq could be divided into the categories "don't know" and "no answer."

As shown in Figure 2, the response "don't know" was more frequent as a reason for not answering the questions than was refusal to answer. This indicates that lack of experience with democracy might offer a better explanation for the missing values for respondents in the Arab world than does fear of the authorities.

\section{Do Arabs Have the Same Understanding of Democracy as Do People Living in Western Democracies?}

The data reveal that most Arabs are able to indicate what they perceive as essential characteristics of democracy. The content of these understandings is obviously important as well. According to Norris (2011), the items we employed in this study measure three different notions of democracy:

1) Procedural democracy: A Western notion covered by the items referring to free elections, referenda votes, civil rights, and equal rights;

2) Instrumental democracy: A notion covered by the items addressing state aid, economic redistribution, prosperous economy, and severe punishment of criminals;

3) Authoritarian democracy: A notion emphasizing additional powers of the military and religious authorities as defining features of democracy.

Figure 3 displays the mean scores attached to the procedural

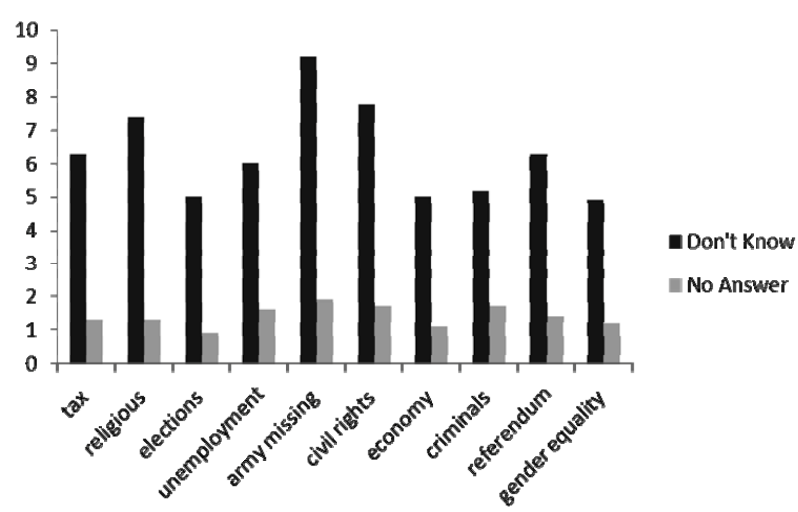

Figure 2.

Percentage "Don't Know" and "No Answer" on defining essential characteristics of democracy in Iraq. Notes: Own calculations WVS 2005.

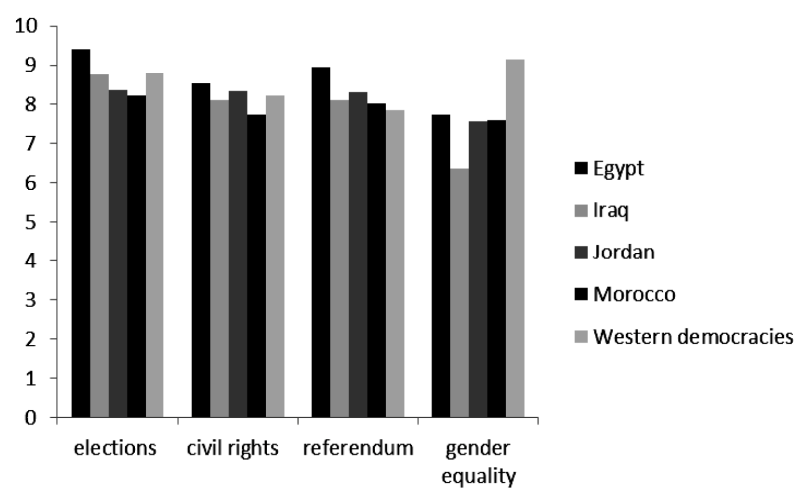

Figure 3.

Mean score importance procedural characteristics of democracy $(1=$ not an essential characteristic and $10=$ an essential characteristic). Notes: Own analysis WVS2005. All differences $p<.001$.

(liberal) characteristics of democracy in Arab countries and in established Western democracies.

As shown in Figure 3, no major discrepancies exist between the Arab countries and Western democracies with regard to the importance attached to the procedural elements of democracy. In several cases (e.g., referendum), Arabs consider these elements more important than Westerners do. The only notable exception is gender equality. As shown in Figure 3, people living in Western democracies were significantly more likely than Arabs were to consider gender equality an essential component of democracy. Respondents in Iraq were particularly likely to attach less value to gender equality as a defining element of democracy. Recall, however, that respondents used a 10-point scale to indicate the extent to which they considered particular aspects essential to democracy. This means that 5.5 is the neutral point of the scale: scores below this point indicate that respondents did not consider the aspect an essential characteristic, and scores above this point indicate that respondents did consider it an important element of democracy. Even though Arabs attach less importance to gender equality than people from Western democracies do, Arabs thus do believe that it is an essential characteristic of democracy.

Some believe that Arabs seek democracy because they believe that such a political system would improve their living conditions. Figure 4 indicates the relative value that Arabs attach to the more instrumental components of democracy. Regarding redistributive policies, the results are mixed. Although Arabs do seem to consider tax policies more important than people from Western democracies do, these differences do not appear to the same extent on the issue of state aid for unemployment. As the figures show, Arabs consider a prosperous economy more important than do people living in Western democracies. The same holds for the severe punishment of criminals. Arabs are more likely than people from Western democracies are to consider this a defining characteristic of democracy.

The largest difference between Arabs and citizens living in Western democracies concerns the role of the army and religious authorities in democracy. Recall that 5.5 is the neutral point of the scale. As shown in Figure 5, respondents from all four Arab countries addressed in this study consider it essential for democracy that religious leaders influence the political process. This is in sharp contrast to respondents from Western democracies, who feel that this is absolutely not an essential characteristic 


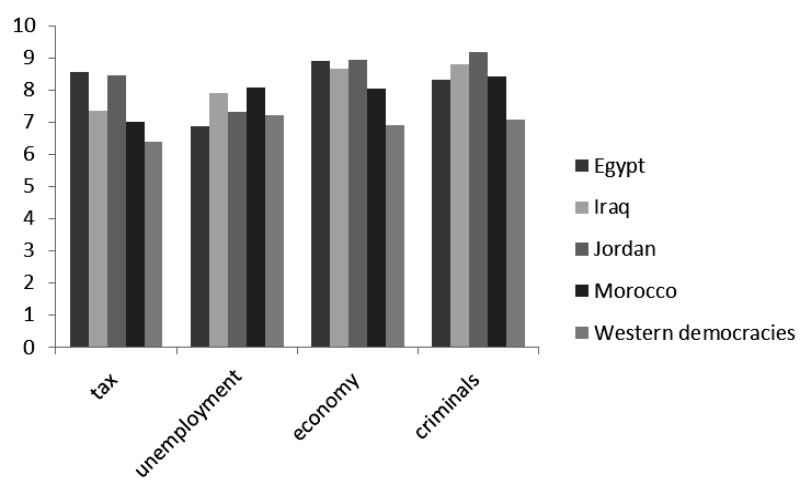

Figure 4.

Mean score importance instrumental characteristics of democracy $(1=$ not an essential characteristic and $10=$ an essential characteristic). Notes: Own analysis WVS 2005. All differences $p<.001$.

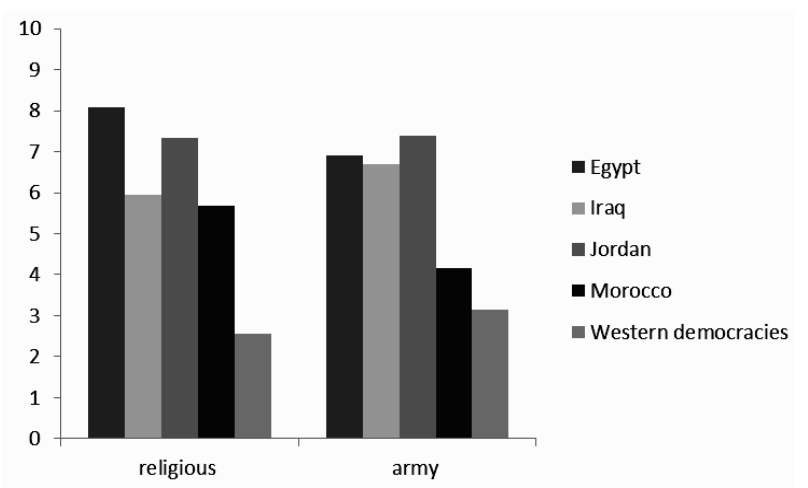

Figure 5.

Mean score importance authoritarian understanding of democracy $(1=$ not an essential characteristic and $10=$ an essential characteristic). Notes: Own analysis WVS 2005. All differences $p<.001$.

of a democratic system.

A similar difference can be observed with regard to the role of the army. Whereas respondents in Western democracies state that, in a democracy, the army should not take over in cases of governmental incompetence, many Arabs feel that such a role for the army is a defining component of democracy.

In Table 1, the components are ranked from most essential (1) to least essential (10). As shown in the table, notable differences exist between Arabs and people living in Western democracies. Gender equality, elections, and civil rights are perceived as the most important components of democracy in Western countries. Whereas free elections are also important for most Arabs, gender equality is among the least essential components for democracy. Another noteworthy difference concerns the "populist" understanding of democracy. While Arabs perceive a prosperous economy and punishing criminals severely as the most important characteristics of democracy, people living in Western democracies attach less value to these components. We should also note that, although Norris (2011) and Welzel (2011) argue that the WVS items measure different components of democracy, explorative factor analysis of the data from the Arab countries indicates a clear unidimensional pattern. For all four countries, all of the items loaded on the same factor. This suggests that Arabs do not distinguish between, for example, authoritarian and liberal notions of democracy.
Table 1.

Ranking essential characteristics democracy in the Arab World.

\begin{tabular}{cccccc}
\hline & Egypt & Iraq & Jordan & Morocco & $\begin{array}{c}\text { Western } \\
\text { democracies }\end{array}$ \\
\hline Tax & 4 & 7 & 3 & 8 & 8 \\
$\begin{array}{c}\text { Religious } \\
\text { leaders }\end{array}$ & 7 & 10 & 9 & 9 & 10 \\
Elections & 1 & 2 & 4 & 2 & 2 \\
$\begin{array}{c}\text { Aid } \\
\text { unemployment }\end{array}$ & 10 & 6 & 10 & 3 & 5 \\
Army & 9 & 8 & 8 & 10 & 9 \\
Civil rights & 5 & 4 & 5 & 6 & 3 \\
Economy & 3 & 3 & 2 & 4 & 7 \\
Criminals & 6 & 1 & 1 & 1 & 6 \\
Referendum & 2 & 5 & 6 & 5 & 4 \\
$\begin{array}{c}\text { Gender } \\
\text { equality }\end{array}$ & 8 & 9 & 7 & 7 & 1 \\
\hline
\end{tabular}

Notes: Own analysis WVS 2005.

\section{Is There Widespread Consensus on the Interpretation of Democracy in the Arab World?}

For democratic transitions to succeed, it is important that people largely agree on how new political institutions should be developed. To provide an indication of consensus in the Arab world regarding the importance of several characteristics of democracy, standard deviations are displayed in Figure 6.

The greatest variation seems to exist with regard to the involvement of religious leaders, the welfare state (tax and state aid in case of unemployment), the role of the army, and gender equality. It is important to examine whether this variation is random or whether structural differences exist between various groups in Arab societies. More specifically, the previous graph raises a number of questions. First, considerable variation exists with regard to the involvement of religious leaders. This variation could be associated with personal levels of religiosity. Second, disagreement exists with regard to redistributive state policies. It could be that people with lower economic status regard the redistribution of wealth as more important than do those in with a more advantageous social economic status. Third, the results reveal differences with regard to whether the army should take over in cases of governmental incompetence. Perhaps this variation could be explained by age differences. In recent years, significant changes have taken place in the countries addressed in this study. For example, Hassan $\Pi$ was king of Morocco from 1961 until 1999. The Years of Lead under this king's rule were characterized by the disappearance, arrest, torture, and murder of dissidents. In 1999, the more liberal King Mohammed VI succeeded his father. The military interventions of 2003 were one of the most significant historical events to take place in Iraq. Events like these may have influenced current views on the role of the army. The issue of whether women should have the same rights as men in democracy is the last issue on which the most disagreement exists. It could be that women in the four Arabic countries addressed in this study are more in favor of gender equality than men are. These questions are addressed in the following paragraphs. 


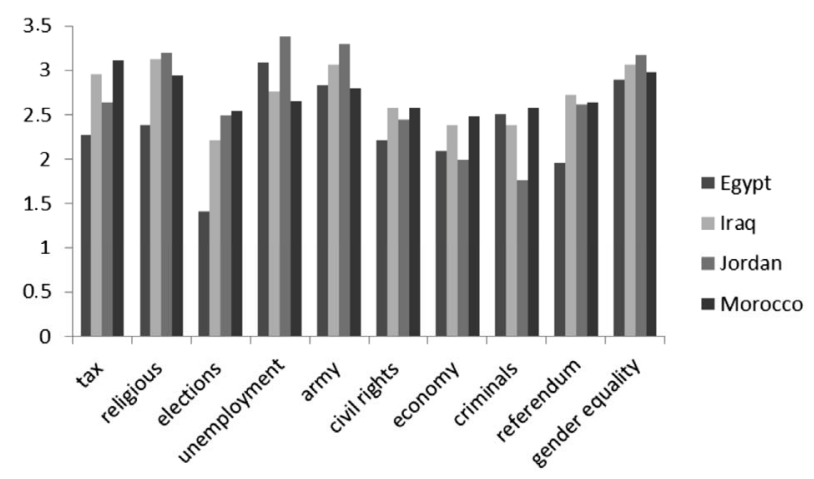

Figure 6.

Standard deviations on characteristics democracy in the Arab world ( $1=$ not an essential characteristic and $10=$ an essential characteristic). Notes: Own analysis WVS 2005. All differences $p<.05$.

First, we examine whether the influence of religious leaders is more important to religious individuals than it is for non-religious individuals. We examined this possibility according to the following question: Independently of whether you attend religious services or not, would you say you are a religious person (1), not a religious person, (2) or an atheist (3) ${ }^{5}$ ? In Egypt, Jordan, and Morocco, about $92 \%$ of the respondents identified themselves as religious, as compared to only $55 \%$ in Iraq. In Egypt and Jordan, there was no significant difference $(p>.05)$ between religious and non-religious individuals regarding the importance attached to religious authorities interpreting the law. As shown in Figure 7, religious people in Iraq and Morocco do attach greater importance to the influence of religious leaders in democracy.

The following issue concerns whether Arabs with lower socio-economic positions regard the redistribution of wealth as more important for democracy than do those with a more advantageous socio-economic position. We investigated this issue according to the following question: Would you describe yourself as belonging to the working class, the middle class, the upper, or the lower class ${ }^{6}$ ? While most respondents in Morocco and Iraq persons indicated belonging to the working class (48.1\% and $41.7 \%$, respectively), most respondents in Egypt and Jordan described themselves as belonging to the middle class $(44.5 \% \text { and } 51.3 \% \text {, respectively })^{7}$. Figures 8 and 9 display the relative importance attached to the two redistribution items by people from different classes.

Figures 8 and 9 point to intra-regional variation regarding

${ }^{5}$ Religiosity is multidimensional, and its measurement is subject to controversy. Because scholars of religiosity disagree regarding the measurement of this concept, we replicated all of the analyses with different operationalisations (i.e., with importance of religion in life, the importance of God in life, the frequency of attending religious services, and praying). This did not alter the main conclusions reported in this article (with a non-significant effect of importance of God in Iraq as the only exception). The results are available from the author upon request.

${ }^{6}$ Self-identification correlates significantly with educational level and household income in all four countries (question on income was not asked in Jordan)

${ }^{7}$ Egypt: lower class (21.6\%), working-class (19.6\%), middle class (44.5\%), and upper class $(14.3 \%)$.

Morocco: lower class (11\%), working-class $(48.1 \%)$, middle class $(33.4 \%)$, and upper class $(7.5 \%)$

Jordan: lower class $(5.9 \%)$, working-class $(15.3 \%)$, middle class $(51.3 \%)$, and upper class $(27.5 \%)$.

Iraq: lower class $(14.9 \%)$, working-class $(41.7 \%)$, middle class $(34.5 \%)$, and upper class $(8.9 \%)$.

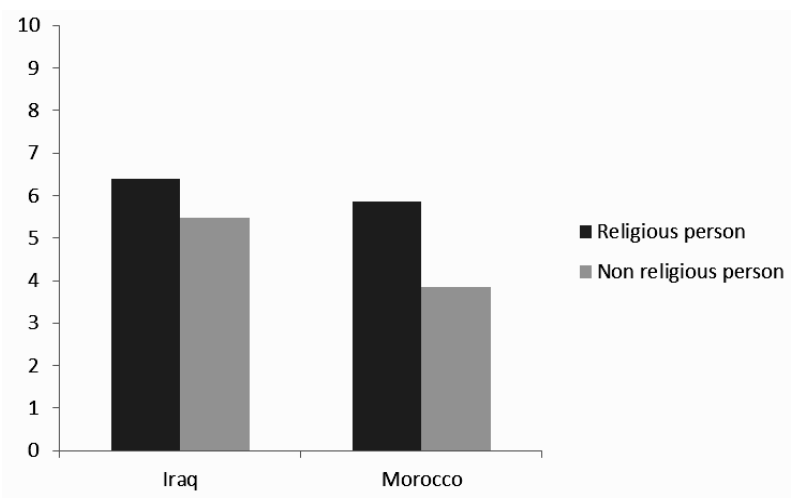

Figure 7.

Mean score importance attached to "Religious leaders interpret the law". $(1=$ not an essential characteristic and $10=$ an essential characteristic $)$. Notes: Own analysis WVS 2005. All differences $p<.001$. Non-religious persons include "not a religious person" and "atheist".

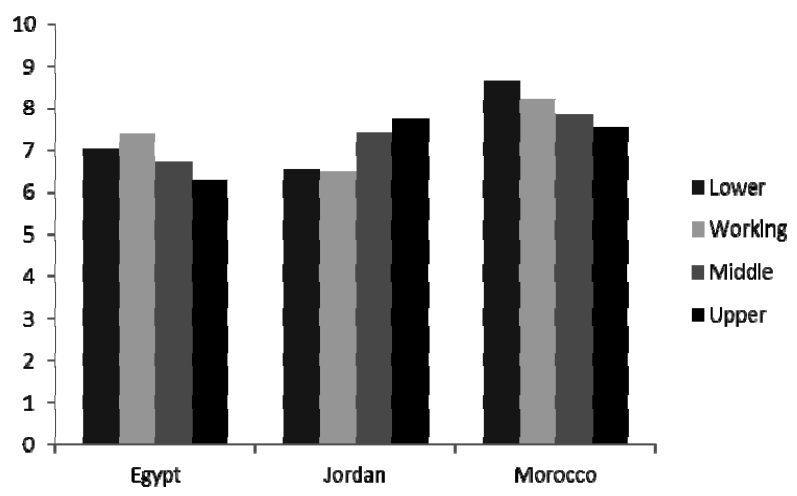

Figure 8.

Mean score importance attached to "receive state aid for unemployment", $(1=$ not an essential characteristic and $10=$ an essential characteristic $)$. Notes: Own analysis WVS 2005. All differences $p<.01$.

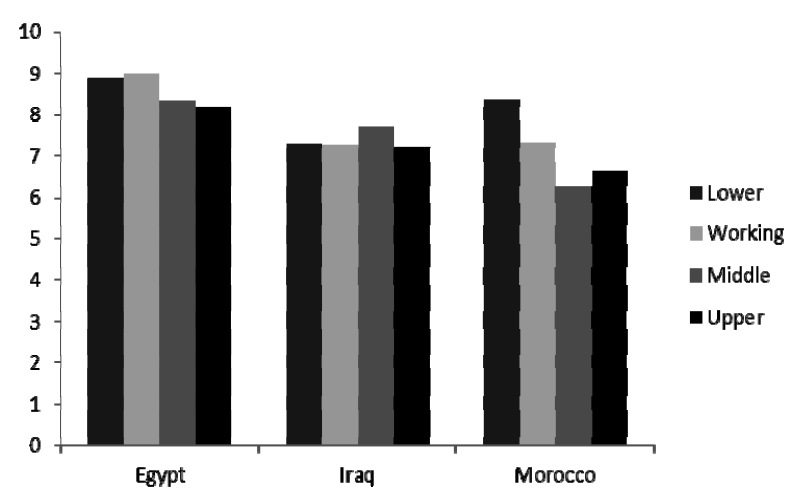

Figure 9.

Mean score importance attached to "tax the rich and subsidize the poor" $(1=$ not an essential characteristic and $10=$ an essential characteristic $)$. Notes: Own analysis WVS 2005. All differences $p<.01$.

class differences in the understanding of democracy. In both Egypt and Morocco, people from higher classes were less likely than those of lower socioeconomic status were to consider tax policies and state aid in case of unemployment as defining components of democracy. In Jordan and Iraq, the results regarding redistributive characteristics were mixed. 
A third issue concerns age differences in the perceived role of the army in democracy. We created five age categories, each covering ten years (e.g., 18 - 27 and 28 - 37). The sixth age category includes people aged 68-97. Given an average life expectancy of about 70 years in Egypt, Iraq, Jordan, and Morocco (73, 68,73 , and 72 years, respectively; see www.data.worldbank.org), too few cases would have been included in more detailed older age categories. In Iraq and Jordan, no significant age differences were found between respondents in these age categories with regard to the role of the army $(p<.05)$. Figure 10 shows the age differences in Egypt and Morocco.

As shown in this figure, older Egyptians and Moroccans are significantly more likely than their younger counterparts are to consider it an important characteristic of democracy for the army to take over in cases of governmental incompetence ${ }^{8}$.

The final issue concerns whether gender equality is a more important component of democracy for Arab women than it is for Arab men.

Gender differences in granting equal rights in democracy appear to be relatively universal. As shown in Figure 11, women in all four Arabic countries consider equal rights for men and women a more important characteristic of democracy than men do. This gender gap is particularly large in Morocco: the mean score for women is about $27 \%$ higher than is that for men $(11 \%, 17 \%$, and 14\%, respectively, in Egypt, Iraq, and Jordan).

\section{Discussion and Conclusion}

Do you think that having a democratic political system would be a good way of governing your country? Is it important for you to live in a democracy? How democratically is your country being governed today? Many studies have analyzed answers to questions containing the abstract term "democracy" (e.g. Esmer, 2002; Huang, Chang, \& Chu, 2008; Massis, 1998). The answers to such questions are difficult to interpret if we do not know exactly how people understand democracy (Canache, Mondak, \& Seligson, 2001; Linde \& Ekman, 2003). This is especially problematic when comparing attitudes towards democracy across contexts (Ariely \& Davidov, 2011). This article shows that the meaning of democracy can vary between individuals, as well as between contexts. More specifically, it provides answers to three main questions. First, it investigates whether Arabs are able to explain what democracy means to them even though they

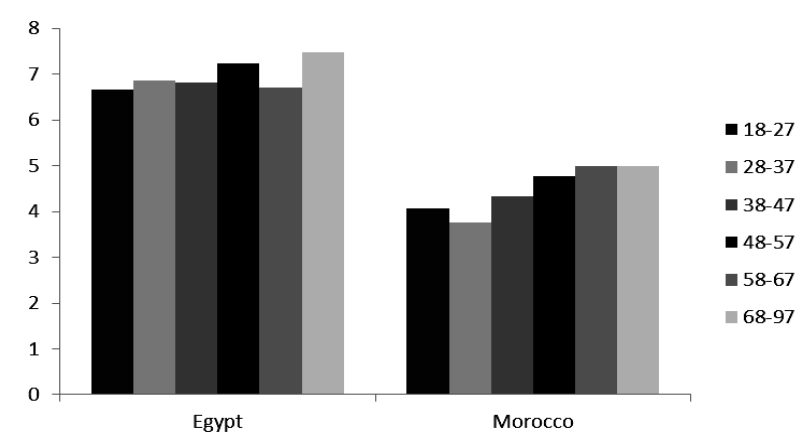

Figure 10.

Mean score importance attached to "Army taking over" $(1=$ not an essential characteristic and $10=$ an essential characteristic). Notes: Own analysis WVS 2005. All differences $p<.01$.

$\overline{{ }^{8} \text { Regression analysis with age as a continuous variable yields identical re- }}$ sults.

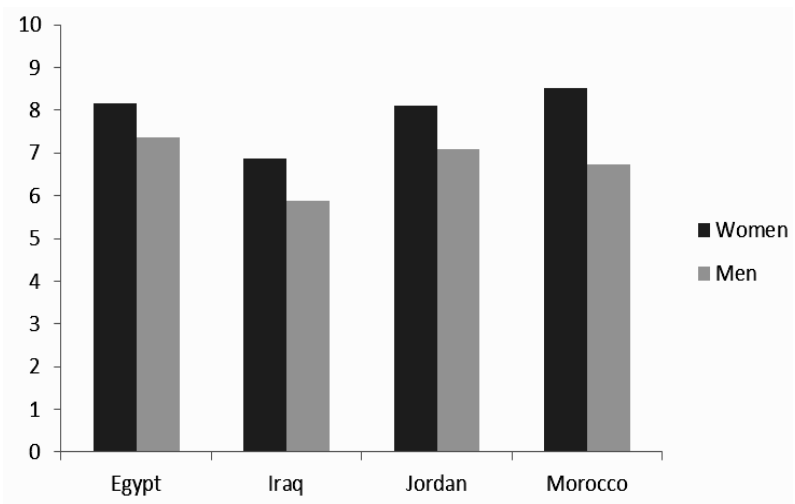

Figure 11.

Gender differences in importance attached to gender equality in a democracy $(1=$ not an essential characteristic and $10=$ an essential characteristic). Notes: Own analysis WVS 2005. All differences $p<.001$.

lack experience with this form of government. Although the number of missing values was highest in Morocco (about 16\%), we can generally conclude that most Arabs are able to indicate how they understand democracy. Analysis of non-response patterns in Iraq indicates that non-response on defining democracy in Arab countries is more likely the result of cognitive deficiency than it is of political fear. Shi (2008) found similar results when analyzing non-response in China.

Second, our analysis identifies the characteristics that Arabs consider most important for democracy. Arabs tend to have a populist notion of democracy (Welzel, 2011), in which a prosperous economy and severe punishment are perceived as the most important elements of democracy. Although Arabs believe that free elections are also very important for a democracy, they attach less value to such procedural aspects as civil rights, liberties, and gender equality. In this respect, they differ from citizens of Western democracies. The last major difference concerns the role of the army and religious leaders. While Arabs believe that political influence on the part of the army and religious leaders can be compatible with democracy, citizens of Western democracies feel that these aspects are incompatible with democracy.

Third, our study reveals considerable variation within Arab societies. The greatest amount of variation was reported with regard to the importance of redistributive policies, the influence of religious leaders, the influence of the army, and gender equality. The results show that differences on these issues are not random, but that they tend to be structural. More specifically, we evaluated whether the belief that religious leaders should have political influence was more important to religious people than it was for non-religious people. The analysis reveals that, in Iraq and Morocco, religious people are more likely than non-religious people are to feel that the influence of religious leaders is important in democracy, while in Egypt and Jordan, the personal level of religiosity is not associated with higher levels of support for political influence on the part of religious leaders. Second, we examine whether people from higher classes are less likely to consider redistributive policies as essential for democracy. This was true in Egypt and Morocco, but the results in Iraq and Jordan on this issue were mixed. Third, the results show that, in Egypt and Morocco, older people are more likely than younger people are to consider it important for the army to be able to take over in cases of governmental incompetence. No generation effects 
were found in Iraq and Jordan. Finally, the results show that, in all countries, women are more likely than men are to consider it essential for democracy that men and women have equal rights.

\section{Fruitful Paths for Future Research}

The findings reported in this article identify several interesting questions that could be examined in future research. Our study reconfirms the existence of substantial differences between Arab countries. It would be valuable to study the influence of country-level attributes on democratic orientations in Arab countries (see also Tessler \& Gao, 2009). Yuchtman-Yaar and Alkalay (2007) showed that both religious heritage and economic context influence modern values held by individual members of society (see also Yuchtman-Ya'ar \& Alkalay, 2010). Islamic heritage (as compared to Protestant) seems to be associated with less modern values, and higher levels of income per capita are associated with values that are more liberal. As these authors noted, more research on contextual effects is needed. In many Arab countries, income inequalities have increased: the rich are getting richer and the poor are getting poorer. For example, in 1997 , Jordan had a Gini index of 36.4. By 2007, this index had increased to $39.7^{9}$. It would be interesting to investigate whether trends in income inequality could explain the attitudes of Arabs towards redistributive policies in democracies. The latest available Arab Human Development Report ${ }^{10}$ points to the structural weakness of many Arab economies and the resulting economic insecurity among citizens. It would be interesting to investigate whether macro-economic factors could explain why so many Arabs feel that a prosperous economy is the most important component of democracy. Levels of ethnic fractionalization differ between Arab countries (Alesina, Devleeschauwer, Easterly, Kurlat, \& Wacziarg, 2003; Fearon, 2003). Future research could investigate whether Arabs living in countries characterized by high levels of heterogeneity are more likely to prefer the army to have a role in democracy.

This article draws upon an analysis of data from only four Arab countries. Although intra-regional variation is partly reflected in these four countries, caution is advised when generalizing the results to the entire region. For some Arab countries, (e.g., Libya, Mauritania, Oman, \& Syria), hardly any survey data on political issues are available. It is hoped that survey data will become available from these countries, thus allowing research on the extent to which the analysis presented in this article is representative of the entire Arab world. In this article, the WVS is used to answer our research questions. Another important source of representative data from the Arab world on political attitudes is the Arab Democracy Barometer (www. arabbarometer.org). The WVS and the Arab Barometer together provide data for Algeria, Egypt, Iraq, Jordan, Kuwait, Lebanon, Morocco, Palestine, Saudi Arabia, and Yemen. The number of countries is expected to increase in the future. Both the WVS and the Arab Barometer launched a new wave in 2010/2011, for which data will become available in the near future. This should facilitate and stimulate detailed research on the influence of both macro and micro determinants of democratic attitudes in the Arab world.

The results reported in this article are based upon data from a single wave. Cross-time analyses in Arab countries are rare (for

\footnotetext{
${ }^{9}$ https://www.cia.gov/library/publications/the-world-factbook/fields/2172.ht $\mathrm{ml} \# 43$

${ }^{10} \mathrm{http}: / /$ www.arab-hdr.org/publications/other/ahdr/ahdr2009e.pdf
}

exceptions see e.g. Meyer, Rizzo, \& Ali, 2007; Moaddel, 2010; Moaddel \& Abdul-Latif, 2007). It would nevertheless be interesting to examine support for democracy across time. Dalton et al. (2007) examined changes in the understanding of democracy following a democratic transition in seven countries. They report that the percentage of respondents answering "don't know" significantly declined following a democratic transition and that institutional and political processes had become more important in people's understanding of democracy. As more data become available in the future, it can be examined whether the understanding of democracy in the Arab World changed in the wake of the Arab Spring. Such investigations could study whether the populace in the Arab World has become more supportive of democracy and whether their interpretation of democracy has shifted in the direction of the liberal Western model of democracy. We have shown that Arabs believe it an essential characteristic of democracy that the army should take over in cases of governmental incompetence. In Egypt, Mubarak's authoritarian regime was replaced by an authoritarian rule of the army. Interesting questions in this regard concern whether this experience changed the way Arabs feel about the role of the army in democracy. Answers to these and other questions should be formulated in future research.

Another interesting path for further research regards the consensus on the form that a democracy should take. It is important to develop a detailed picture of structural variation within Arab societies. In this article, we examine the effects of religiosity, class, age, and gender on the understanding of democracy. Other factors might influence the ways in which people comprehend democracy. One example concerns the difference between the elite and the masses. Research in post-Soviet societies demonstrates that, while the elite tend to emphasize law and order and the rule of law, citizens stress freedom in their understanding of democracy (Miller et al., 1997). It would be interesting to investigate whether this finding could be generalized to Arab countries or whether people with more experience travelling to Western countries are more likely to emphasize procedural and liberal aspects of democracy. An additional question for future investigation concerns whether people with high levels of social and economic mobility in Arab countries are less likely to feel that redistributive policies are important for democracy. Other factors of interest for further research include media consumption, interest in political affairs, and ethnicity.

\section{What Can We Tell about the Process of Democratization in the Arab World?}

Perceptions of democracy do have consequences for the public's expectations of and satisfaction with political developments (Camp, 2001). The results reported in this article could have practical implications for the Arab world. The finding that Arabs tend to equate democracy with a prosperous economy might be problematic for the emergence of democratic systems in the Arab world. On the one hand, Arabs might become dissatisfied with future democratic transitions if they are not accompanied with better material living conditions. On the other hand, support for democracy might decrease as the economic situation in Arab countries improves. The relationship between a prosperous economy and the emergence of democratic institutions is unclear (Glaeser, La Porta, Lopez-de-Silanes, \& Shleifer, 2004). It remains to be seen whether and to what extent the process of democratization and economic conjecture are intertwined in the 
Arab world.

The position of women in Muslim-majority countries is a highly debated topic (Meyer, Rizzo, \& Ali, 1998). As this article shows, Arabs are less likely to consider gender equality an essential characteristic of democracy than are people living in free Western democracies. In Jordan and Morocco, respondents ranked gender equality seventh out of the ten aspects of democracy; it was ranked eighth in Egypt and ninth in Iraq. In March 2012, a 16-year-old Moroccan girl committed suicide after she was forced to marry a man who had raped her. The finding that equal rights for men and women play such an unimportant role in the democratic perceptions of many Arabs might raise doubts concerning whether the process of democratization in the Arab world would extend the rights of women. We must note, however, that Arabs in general do not appear to be opposed to gender equality. Although they do not see it is one of the most important aspects of a democracy, they still believe that gender equality is a necessary component of democracy. The extent to which women will have a permanent stake in shaping democracy in the Arab world remains to be seen.

There are multiple normative models of democracy, including libertarian democracy, liberal democracy, and socialist democracy (see e.g. Fuchs, 1999 for a short review). One of the most notable differences between Western and Arab countries concerns the influence of religious leaders in democracy. The first parliamentary elections after Mubarak's reassignment were won by the Muslim Brotherhood (Freedom and Justice Party), which is known for its slogan "Islam is the Solution." This victory is feared by many people in the West, in part because of the party's promotion of Sharia law. The fact that many Arabs prefer Islam to play a role in political processes is partly a reaction to its previous suppression by secular colonization powers, secular authoritarian Arab leaders, and economic deprivation (see e.g. Tessler, 1997 for more information on support for Islamist movements in Arab societies and Breznau et al. (2011) for differences between Christians and Muslims in preference for religious political leaders). Jamal and Tessler (2008) observe that Arabs who prefer a secular democracy do not differ significantly with respect to several democratic orientations (i.e., respect for political diversity, social tolerance, and gender equality). This indicates that, despite what many people in the West might think, democratic systems in which religious leaders have political influence might not necessarily have undemocratic outcomes. We agree with Camp (2001) that neither the United States nor any long standing Western-style democracy can lay an exclusive claim to defining the meaning of democracy. Given that most Arabs would prefer a democratic political system, we hope that the Arab Spring will result in the emergence of more democracies in the Arab world. Time will tell whether political influence on the part of Islamic leaders can be compatible with democracy.

\section{REFERENCES}

al-Braizat, F. (2002). Muslims and democracy_An empirical critique of Fukuyama's culturalist approach. International Journal of Comparative Sociology, 43, 269-299. doi:10.1177/002071520204300304

Alesina, A., Devleeschauwer, A., Easterly, W., Kurlat, S., \& Wacziarg, R. (2003). Fractionalization. Journal of Economic Growth, 8, 155194. doi:10.1023/A:1024471506938

Arensmeier, C. (2010). The democratic common sense. Young Swedes' understanding of democracy-Theoretical features and educational incentives. Young, 18, 197-222. doi:10.1177/110330881001800205
Ariely, G., \& Davidov, E. (2011). Can we rate public support for democracy in a comparable way? Cross-national equivalence of democratic attitudes in the World Value Survey. Social Indicators Research, 104, 271-286. doi:10.1007/s11205-010-9693-5

Bratton, M. (2003). Briefing: Islam, democracy and public opinion in Africa. African Affairs, 102, 493-501. doi:10.1093/afraf/adg049

Bratton, M., \& Mattes, R. (2001). Africans' surprising universalism. Journal of Democracy, 12, 107-121. doi:10.1353/jod.2001.0002

Camp, R. A. (2001). Democracy through Latin American lenses. An appraisal. In R. A. Camp (Ed.), Citizen views of democracy in Latin America (pp. 3-23). Pittsburgh: University of Pittsburgh Press.

Canache, D. (2006). Measuring variance and complexity in citizens' understanding of democracy. Prepared for the LAPOP-UNDP Workshop: Candidate Indicators for the UNDP Democracy Support Index (DSI), Nashville, TN: Vanderbilt University.

Canache, D., Mondak, J. J., \& Seligson, M. A. (2001). Meaning and measurement in cross-national research on satisfaction with democracy. Public Opinion Quarterly, 65, 506-528. doi:10.1086/323576

Chu, Y.-H., Diamond, L., Nathan, A. J., \& Shin, D. C. (2008). Introduction: Comparative perspectives on democratic legitimacy in East Asia. In G. A. Chung-Yan, L. Diamond, A. J. Nathan, \& D. C. Shin (Eds.), How East Asians view democracy (pp. 1-38). New York: Columbia University.

Ciftci, S. (2010). Modernization, Islam, or social capital: What explains attitudes toward democracy in the Muslim world? Comparative Political Studies, 43, 1442-1470. doi:10.1177/0010414010371903

Dahl, R., Shapiro, I., \& Cheibub, J. (2003). The democracy sourcebook. London: The MIT Press.

Dalton, R. J., Shin, D. C., \& Jou, W. (2007). Understanding democracy: Data from unlikely places. Journal of Democracy, 18, 142-156.

Diamond, L. (1999). Developing democracy: Toward consolidation. Baltimore: Johns Hopkins University Press.

Diamond, L., \& Plattner, M. F. (2008). How people view democracy. Baltimore: The John Hopkins University Press.

Díez-Nicolás, J. (2007). Value systems of elites and publics in the Mediterranean: Convergence or divergence. New York: Palgrave MacMillan.

Dixon, J. C. (2008). A clash of civilizations? Examining liberal-democratic values in Turkey and the European Union. British Journal of Sociology, 59, 681-708. doi:10.1111/j.1468-4446.2008.00215.x

Esmer, Y. (2002). Is there an Islamic civilization? Comparative Sociology, 1, 265-298. doi:10.1163/156913302100418600

Fearon, J. D. (2003). Ethnic and cultural diversity by country. Journal of Economic Growth, 8, 195-222. doi:10.1023/A:1024419522867

Fish, M. S. (2002). Islam and authoritarianism. World Politics, 55, 4-37. doi:10.1353/wp.2003.0004

Fuchs, D. (1999). The democratic culture of unified Germany. In P. Norris (Ed.), Critical citizens. Global support for democratic government (pp. 123-145). Oxford: Oxford University Press.

Glaeser, E., La Porta, R., Lopez-de-Silanes, F., \& Shleifer, A. (2004). Do institutions cause growth? Journal of Economic Growth, 9, 271303. doi:10.1023/B:JOEG.0000038933.16398.ed

Grant, A., \& Tessler, M. (2002). Palestinian attitudes toward democracy and its compatibility with Islam: Evidence from public opinion research in the West Bank and Gaza. Arab Studies Quarterly, 24, 119.

Hofmann, S. R. (2004). Islam and democracy-Micro-level indications of compatibility. Comparative Political Studies, 37, 652-676. doi: $10.1177 / 0010414004265881$

Huang, M.-H. (2005). Islam and democracy: A global perspective. Taiwan Journal of Democracy, 1, 109-137.

Huang, M.-H., Chang, Y.-T., \& Chu, Y.-H. (2008). Identifying sources of democratic legitimacy: A multilevel analysis. Electoral Studies, 17, 45-62. doi:10.1016/j.electstud.2007.11.002

Huntington, S. P. (1993). The clash of civilizations. Foreign Affairs, 72, 22-49. doi: $10.2307 / 20045621$

Ikeda, K., \& Kohno, M. (2008). Japanese attitudes and values toward democracy. In G. A. Chung-Yan, L. Diamond, A. J. Nathan, \& D. C. Shin (Eds.), How East Asians view democracy (pp. 161-186). New York: Columbia University.

Inglehart, R. (2003). How solid is mass support for democracy-And 
how can we measure it? Ps-Political Science \& Politics, 36, 51-57. doi:10.1017/S1049096503001689

Inglehart, R., \& Norris, P. (2003). The true clash of civilizations. Foreign Policy, 135, 62-70. doi:10.2307/3183594

Inglehart, R., Norris, P., \& Welzel, C. (2002). Gender equality and democracy. Comparative Sociology, 1, 321-345. doi: $10.1163 / 156913302100418628$

Jamal, A. (2006). Reassessing support for democracy and Islam in the arab world: Evidence from Egypt and Jordan. World Affairs, 169, 5163. doi:10.3200/WAFS.169.2.51-63

Jamal, A., \& Tessler, M. (2008). The Arab aspiration for democracy. In L. Diamond, \& M. F. Plattner (Eds.), How people view democracy (pp. 129-142). Baltimore, MD: The John Hopkins University Press.

Linde, J., \& Ekman, J. (2003). Satisfaction with democracy: A note on a frequently used indicator in comparative politics. European Journal of Political Research, 42, 391-408. doi:10.1111/1475-6765.00089

Maslow, A. H. (1943). A theory of human motivation. Psychological Review, 50, 370-396. doi:10.1037/h0054346

Massis, M. (1998). Jordan: A study of attitudes toward democratic changes. Arab Studies Quarterly, 20, 37-63.

Meyer, K., Rizzo, H., \& Ali, Y. (1998). Islam and the extension of citizenship rights to women in Kuwait. Journal for the Scientific Study of Religion, 37, 131-144. doi:10.2307/1388033

Meyer, K., Rizzo, H., \& Ali, Y. (2007). Changed political attitudes in the Middle East-The case of Kuwait. International Sociology, 22, 289-324. doi:10.1177/0268580907076571

Meyer, K., Tope, D., \& Price, A. M. (2008). Religion and support for democracy: A crossnational examination. Sociological Spectrum, 28, 625-653. doi:10.1080/02732170802206260

Midlarsky, M. I. (1998). Democracy and Islam: Implications for civilizational conflict and the democratic peace. International Studies Quarterly, 42, 485-511. doi:10.1111/0020-8833.00093

Miller, A. H., Hesli, V. L., \& Reisinger, W. M. (1997). Conceptions of democracy among mass and elite in post-Soviet societies. British Journal of Political Science, 27, 157-190.

doi:10.1017/S0007123497000100

Moaddel, M. (2010). Religious regimes and prospects for liberal politics: Futures of Iran, Iraq and Saudi Arabia. Futures, 42, 532-544. doi:10.1016/j.futures.2010.01.004

Moaddel, M., \& Abdul-Latif, A. (2007). Events and value change: The impact of September 11, 2001 and the worldviews of Egyptians and Moroccans. In M. Moaddel (Ed.), Values and perceptions of the Islamic and Middle Eastern publics. New York: Palgrave MacMillan. doi:10.1057/9780230603332

Mogahed, D. (2006). Islam and democracy Gallup World Poll. Special report: Muslim World. Princeton, NJ: The Gallup Organization.

Moghadam, V. M. (2004). Towards gender equality in the Arab/Middle East region: Islam, gender, and feminist activism Background paper of HDR 2004. New York: Human Development Report Office.

Moreno, A. (2001). Democracy and mass belief systems in Latin America. In R. A. Camp (Ed.), Citizen views of democracy in Latin America (pp. 27-50). Pittsbugh: University of Pittsburgh Press.

Norris, P. (1999). Global support for democratic government. Oxford: Oxford University Press.

Norris, P. (2011). Democratic deficit. Critical citizens revisited. Cambridge: Cambridge University Press. doi:10.1017/CBO9780511973383

Norris, P., \& Inglehart, R. (2002). Islamic culture and democracy: Testing the "clash of civilizations" thesis. Comparative Sociology, 1, 235-263. doi: $10.1163 / 156913302100418592$

Norris, P., \& Inglehart, R. (2004). Religion and politics in the Muslim world. In P. Norris \& R. Inglehart (Eds.), Sacred and secular. Religion and politics worldwide (pp. 133-156). Cambridge: Cambridge
University Press. doi:10.1017/CBO9780511791017.008

Rizzo, H., Abdel-Latif, A.-H., \& Meyer, K. (2007). The relationship between gender equality and democracy: A comparison of Arab versus non-Arab Muslim societies. Sociology-the Journal of the British Sociological Association, 41, 1151-1170. doi: $10.1177 / 0038038507082320$

Rose, R. (2002). How Muslims view democracy: Evidence from Central Asia. Journal of Democracy, 13, 102-111. doi: 10.1353/jod.2002.0078

Schedler, A., \& Sarsfield, R. (2007). Democrats with adjectives: Linking direct and indirect measures of democratic support. European Journal of Political Research, 46, 637-659.

doi:10.1111/j.1475-6765.2007.00708.x

Schumpeter, J. (1942). Capitalism, socialism and democracy. New York: Harper and Brothers.

Seligson, M. (2001). Costa Rican exceptionalism. Why the Ticos are different. In R. A. Camp (Ed.), Views of democracy in Latin America (pp. 90-106). Pittsburgh: University of Pittsburgh Press.

Shi, T. (2008). Democratic values supporting an authoritarian regime. In Y.-H. Chu, L. Diamond, A. J. Nathan, \& D. C. Shin (Eds.), How East Asians view democracy (pp. 209-237). New York: Columbia University Press.

Shin, D. C., \& Cho, Y. (2010). How East Asians understand democracy: From a comparative perspective. Asien, 116, 21-40.

Sigel, R. S. (1979). Students' comprehension of democracy and its application to conflict situations. International Journal of Political Education, 2, 47-65.

Stevens, D., Bishin, B. G., \& Barr, R. R. (2006). Authoritarian attitudes, democracy, and policy preferences among Latin American elites. American Journal of Political Science, 50, 606-620. doi:10.1111/j.1540-5907.2006.00204.x

Tessler, M. (1997). The origins of popular support for Islamist movements: A political economy analysis. In J. Entelis (Ed.), Islam, democracy, and the state in North Africa. Bloomington, IN: Indiana University Press.

Tessler, M. (2002a). Do Islamic orientations influence attitudes toward democracy in the Arab world? Evidence from Egypt, Jordan, Moro$\mathrm{cco}$, and Algeria. International Journal of Comparative Sociology, 43, 229-249. doi:10.1177/002071520204300302

Tessler, M. (2002b). Islam and democracy in the Middle East-The impact of religious Orientations on attitudes toward democracy in four Arab countries. Comparative Politics, 34, 337-354. doi: $10.2307 / 4146957$

Tessler, M., \& Gao, E. (2005). Gauging Arab support for democracy. Journal of Democracy, 16, 83-97. doi:10.1353/jod.2005.0054

Tessler, M., \& Gao, E. (2009). Democracy and the political culture orientations of ordinary citizens: A typology for the Arab world and beyond. International Social Science Journal, 192, 197-207.

Tessler, M., Moaddel, M., \& Inglehart, R. (2006). What do Iraqis want? Journal of Democracy, 17, 38-50. doi:10.1353/jod.2006.0019

Toros, E. (2010). The relationship between Islam and democracy in Turkey: Employing political culture as an Indicator. Social Indicators Research, 95, 253-265. doi:10.1007/s11205-009-9458-1

Welzel, C. (2011). The Asian values thesis revisited: Evidence from the World Values Surveys. Japanese Journal of Political Science, 12, 131.

Yuchtman-Ya'ar, E., \& Alkalay, Y. (2007). Religious zones, economic development and modern value orientations: Individual versus contextual effects. Social Science Research, 36, 789-807. doi:10.1016/i.ssresearch.2006.06.004

Yuchtman-Ya'ar, E., \& Alkalay, Y. (2010). Political attitudes in the Muslim world. Journal of Democracy, 21, 122-134.

doi:10.1353/jod.0.0183 